\title{
Sustainable Peace: Developing Peace Education Based on Sustainable Coastal-Tourism in Ciantir and Badegur Coasts, Banten, Indonesia
}

\author{
Hengky, S. H. \\ Director of SHINE InstituteP \\ Associate Professor, Triguna Economic School
}

Received: August 19, 2014

Accepted: Oct 22, 2014

Published: October 22, 2014

doi:10.5296/jmr.v6i4.6466

URL: http://dx.doi.org/10.5296/jmr.v6i4.6466

\begin{abstract}
The aim of the research is to develop sustainable peace education in Ciantir and Badegur Coastal tourism, Banten, Indonesia based on sustainable tourism, and responding to the statement of the Minister of Tourism and Creative Economy. This study is essential in addressing the conflict over space: social, environmental, and territorial, because it's become the basis for sustainable peace education. The research is conducted from July 2013 - July 2014. Randomly and stratified sampling of 200 respondents, using triangulation technique. The collected data were tabulated by using the content analysis. This study shows that until now the development of the coastal of Ciantir and Badegur would addressing the space conflict, increasing income per capita, decreasing unemployment and poverty due to the low quality of human resources, and decreasing degradation of the natural environment. The main points that would be enhanced by strengthening the basis of sustainable peace education: Firstly, political will of the local government need to be enhanced in the future to improve the performance of sustainable peace; and Secondly, cross-cultural interaction and form interaction would be improved as well. However, these interactions stimulate dialogue and exchange, break down cultural barriers and promote the values of tolerance, and mutual understanding and respect. The values espoused by the tourists are integral in building a future more peaceful and tolerant.
\end{abstract}

Keywords: Sustainable Peace, Conflict social, Conflict resource, Cross-cultural interaction 


\section{Introduction}

Geographically from Sabang to Merauke, Indonesia's resources are highly influenced by the geographical aspects of spatial, environmental and territorial, is the cornerstone of national development aimed at the welfare of the people. With Indonesia's population of around 250 million people more by the Head of the National Population and Family Planning, as well as a wealth of natural and cultural diversity that unfolds throughout the archipelago, is an important asset for the successful implementation of development in Indonesia.

The fact that the implementation of development in Indonesia is still felt by the people is not optimal, especially with the majority of which are in rural areas and particularly in Eastern Indonesia. One of the obstacles is not an optimal national development in rural areas, which is according to the BPS (2012) of around 78,000 villages and spread over thousands of islands, is a geographical condition. This led to the development of social infrastructure, especially in rural areas are not able to be implemented evenly.

As a result, until now the development in Indonesia has led to a variety of multi-dimensional problems include, among others, less inequality of development between regions that cause conflict, decline in per capita income due to increasing population, rising unemployment and poverty due to the low qualities of human resources, the increasing degradation of the natural environment due to the use of highly exploitative, the weakening of national identity due to the lack of appreciation of the cultural identity and character of the nation and even the rampant commodification of culture.

According to the World Bank (2014), despite the decline in poverty in Indonesia continued to slow, the rate of decline of just 0.7 percent for the years 2012 to 2013 - the smallest rate of decline in the last decade. Inequality also increased in recent years with the potential to create social conflict. This will reduce the benefits of high economic growth the past few years, the growth of which is essential to reduce the level of poverty to $11.3 \%$ in 2014 , compared with 24\% in 1999 (Admin, 2014).

Therefore, in an effort to accelerate the development of future programs better, necessary reference materials for the next administration, 2014-2019 Platform or Policy of sustainable tourism development strategy of rural based. As noted by the Minister of Tourism and Creative Economy at the World Economic Forum in Bangkok, that tourism is important not only because of its contribution to GDP and employment, but also to promote sustainable development through sustainable tourism (Antara, 2012). It is strengthened by the statement of the Deputy Minister of Tourism and Creative Economy, Sapta Nirwandar, said the growth of the tourism industry in Indonesia in 2014 reached 9.39 per cent higher than the previous year. That figure is above the national economic growth reaches 5.7 percent (Berlin, 2014).

At the same time, the data from the Ministry of Tourism and Creative Economy, in 2013, the tourism sector, in particular of tourist arrivals successfully contributed income of US \$ 10.054 billion. While the impact on other sectors, can be seen from the data consumption patterns of foreign tourists. The highest percentage of freight is held by $44.3 \%$, then the accommodation of $11.2 \%$. Furthermore, the food and beverage industry, which amounted to 
$17.67 \%$, the fourth is a souvenir of $7.87 \%$ and the fifth was a product of fashion and craft of 6.24\% (Liliyah, 2014)

The Background chooses Banten as the study area, because it is located close to the International airport of the capital city of Indonesia, and responding to the statement of the Minister of Tourism and Creative Economy (Antara, 2012). The aim of the research is to develop sustainable peace education based on sustainable tourism.

\section{Literature Review}

Tourism, as peace is very fragile and easily damaged. There are many examples of how the political crisis, security threats, financial collapse, and natural disasters or military conflicts can seriously damage or even destroy tourism in particular regions or countries. The peace, which so fragile and highly dependent on the quality of human relationships. Prejudice, misunderstanding and intolerance is the root cause of the destruction of peace. That is why tourism is an ally of peace. Tourism to establish a contact between the tourists and local people with different cultures and different social-economic. The tourists can feel the peace and harmony of with the local community which have received and make the tourists feel safe and comfortable in traveling. Activity of cross-border tourism, the tourists visiting new places and find different cultures. It becomes a learning process for tourists which can give a deep impression to the tourists and to form a policy based interactions. Learning this will make them more tolerant to interact and will tear down the divisions between nations of the world. This condition will open the eyes of everyone's heart in seeing each other with the uniqueness of each culture, values, history, traditions, and customs (Villiers, 2014).

With more than one billion travelers around the world each year, tourism has become a social and cultural phenomenon in the entire world involving people from various nations both as hosts and tourists. Experience in the tourism base to visit new places and meet people with different social-economic and cultural, is transformative aspect that defines the role of tourism as an agent of peace (UNWTO, 2014).

During the tour, the tourists also interact with a variety of unique local culture. These interactions stimulate dialogue and exchange, break down cultural barriers and promote the values of tolerance, and mutual understanding and respect. The values espoused by the tourists is integral to building a future more peaceful and tolerant. Indeed, peace is the most important thing in travel and tourism, and also important for social growth and the education of sustainable peace. It is the basis and background for sustainable tourism has been praised as a support and a pioneer "Global Peace Industry" (UNWTO, 2014).

Referred to the Minister of Tourism and Creative Economy, Bajaj \& Chiu (2009) tracing the intersection of two disciplines, namely between peace education and environmental education, and they are trying to understand how the harmony of framework of peace education for sustainable development. Moreover, they also explore the role of the UN in promoting and empowering each individual to participate in advancing the objectives of peace and ecological sustainability. As a result, they found that the UN's role is essential in the reinforcement of peace education and environmental education in the promotion of 
Sustainable Development (Kelman, 1998), particularly in formal education, non-formal learning channels, and popular culture in building a holistic idea of the ecological responsibility, peace, and social justice.

Recent research conducted by Brakes and Addo (2014) find that the key success factors of sustainable management of coastal tourism depend on the efficient management of tourism resources that are natural, cultural, and environmentally friendly. The results of the management of sustainable tourism can be used as: Social-economic interaction facilities and culture; and Efforts to promote the values of tolerance, and mutual understanding and respect across social-economic and cultural. This is the basis for sustainable peace education advocates.

At the same time, Nara, Mao, and Yen (2014), explores the environmental management policies as well as a variety of the coastal tourism strategies and the efforts to address the environmental impact and sustainable development. As a result, they found that the policies and management of sustainable development in a sustainable coastal tourism industry into the dot is the beginning of a sustainable development of peace education.

Moreover, Hengky (2014) found that government policy strongly supports the structuring of the rearrangement in the management of coastal tourism by way of zoning and landscaping can improve environmental protection and competitiveness. With increasing environmental protection and coastal tourism competitiveness, will improve environmental performance, social-economic, cultural and coastal communities. This will be an attraction in a place of coastal tourism interaction between the tourists and local people, and the basis for interaction, learning, tolerance, mutual understanding and respect each other's culture. Based on the interaction, understanding, tolerance, and cross-cultural appreciation will be the basis of a sustainable peace education.

While, Senlier \& Ozturk (2011) examined the usefulness of models of sustainable coastal tourism for the purpose of defining the life cycle of the coastal tourism areas. Sustainable coastal tourism should be supported by tourism policies and environmental regulations, because it has more natural diversity attract more people but intensive visit. As an undeniable fact, sustainable coastal tourism becomes current tourism trends as well as a place of interaction between regions and countries and cultures. This is the basis for sustainable peace education with basic education, tolerance, and mutual understanding.

Previously research by Marvis (2011) found that the island as an understanding of the value of coastal resources at risk, and the future orientation of management toward sustainable utilization. This study is intended as a platform for discussion, presented a number of recommendations on sustainable coastal tourism, and aimed at large institutions and political environment. Thus the risk management of coastal tourism will determine how coastal tourism development is strongly influenced by the quality and environmental performance, especially coastal areas. He identifies that coastal tourism operators attempt to overcome the negative impact of the environment is influenced by the political will of the local government, and the performance of coastal tourism is becoming the platform of cross-cultural interaction 
and form of interaction, understanding, and cross-cultural tolerance, which the basis for sustainable peace education.

\section{Methodology}

The research is conducted from July 2013 - July 2014, for addressing the conflict over space: social, environmental. At the same time, responding the statement of the Minister of Tourism and Creative Economy, at Banten, Indonesia. Randomly and stratified sampling of 200 respondents were from local and coastal community, several tour operators, hotel and travel agency, and related institutions, using triangulation technique (Jenning, 2001): Open observation; Structure interview; and Interview. The collected data was tabulated by using the content analysis (Ello \& Kyngas, 2008; Riffe, Lacy, \& Fico, 1998; and Cohen. 1960) based on the sustainable coastal tourism (Nara, Mao, \& Yen, 2014; and Brake \& Addo, 2014) and sustainable peace education (Marvis, 2014; Hengky, 2014; Senlier \& Ozturk, 2011; UNWTO, 2014; and Bajaj \& Chiu, 2009): Exploring, the performance of sustainable coastal tourism, political will of the local government, cross-cultural interaction and form interaction, and understanding and cross-cultural tolerance; Posting each parameter of the sustainable coastal tourism and sustainable peace education; Sustainable coastal tourism and Sustainable peace education frequency matched; Sustainable coastal tourism and sustainable peace education counted; and Result and analysis (Riffe at al., 1998; and Henderson, 1991).

\section{Result and Discussion}

\subsection{Ciantir's Coast}

Based on sustainable peace education (Marvis, 2014; Hengky, 2014; Senlier \& Ozturk, 2011; UNWTO, 2014; and Bajaj \& Chiu, 2009), which presented in Table 1, it indicates there is a potential of Ciantir's coastal tourism to address the conflict of space based on sustainable peace education $(\mathrm{K}=0.695)$. The performance of the Ciantir coast well known to have a wide variety of natural attractions (\% Freq $=28.06$ ), is worth visiting during the holidays arrive. This beach is located in the area of Kampung Gendol, Lebak district of Banten Province. The Nature of Ciantir's coast is located approximately $150 \mathrm{~km}$ from the city center Rangkasbitung (Masun, 2014).

The presence of a suspension bridge and walking trails have become one of the icons to the beach and Tanjunglayar Ciantir preferred by the tourists. When tracing the trail, tourists really enjoy the friendliness of its people and after going through the traditional village scenery unfolds paddy fields and traditional processing activities that are rarely encountered by urban residents (Oktariadi, 2012). 
Table 1. Results Tabulation Ciantir’s Coast

\begin{tabular}{lll}
\hline Ciantir's Coast - Sustainable Peace Education & Value & \% Freq \\
\hline The performance of sustainable coastal tourism & 39 & 28.06 \\
Political will of the local government & 28 & 20.14 \\
Cross-cultural interaction and form interaction & 32 & 23.02 \\
Understanding and cross-cultural tolerance & 40 & 28.78 \\
\hline
\end{tabular}

Kappa Coefficient $=\mathrm{K}=0.695$

In the mean time, there is a white sand and rows of coconut trees and a charming ocean wave at Ciantir's coast. This beach is the most visited by tourists who come to the village Sawarna. In addition to its wonderful charm, the beach is also close to the inn there. The coast headland screen also gives coolness to anyone who looked at him. This stretch of coast surrounding reef, with 2 reefs towering up and became an icon of Sawarna (Milah, 2013).

The beauty of nature is tucked the coast overlooking the Indian Ocean. The beach has white sand, clear blue waters and lush green hills. Ciantir coast, which has reached $65 \mathrm{~km}$ long coral decorated with a variety of sizes as well as a row of palm trees. Many say that this Ciantir Coast is the most beautiful the coast owned by the province of Banten.

This beach offers beautiful scenery and stunning beaches with waves suitable for surfing spots, a lot of tourists coming from different parts of the country such as Japan, Australia, and Korea to try surfing at this beach. Ciantir coast is also famous for the cave, one of the caves contained in this beach is the bat cave, the dwelling place of Thunderbird bats. In addition, visitors can also watch the wildlife and crystal clear water that flows down the cave.

The Ciantir's coast is one of the beaches that made the favorite choice of national and international surfers. With high waves and heavy, I wonder if the new mid-year or year is always crowded with tourists who like to surf. As normal conditions beaches elsewhere, this beach often used by the tourists with their friends on enjoying the evening sun is orange, until sunset on the western horizon there.

Sometimes, the tourists will find some fisherman who is eager to tuna fishing in coastal edges using cane poles-which typically-sized long enough. When the handle of the rod length it is less, then they will seek the tongues of coral rock that stretched piercing sea. Shore coral clusters

The late afternoon is the best time to enjoy the beauty of the beach of Ciantir. Tranquil atmosphere, away from the crowds of the street, making it into a perfect beach vacation alternative. Unfortunately, a tourist could not swim even though it was on the beach, as the waves of the southern ocean is so high. But that does not mean it cannot enjoy the beach right? 
The proof, the southern sea coast is often visited by foreign tourists who want to feel the sensation of surfing.

Nevertheless, the main problem is accessibility and it reflects from the time to reach the coast is about 7 hours drive from Jakarta to Lebak, Banten, drove the tourists to a suspension bridge made of wood. The bridge is the only access to get into the village Sawarna. Simple bridge 50 meters long with a width of no more than one meter of this, be vital for both pedestrians and motorists. "Simplicity" is a suspension bridge makes Sawarna has a unique village. After climbing the bridge "rocking”, a variety of simple home-stay seen standing in between the houses of local residents (Partodirejo, 2012; and Wisata, 2011).

The cross-cultural interaction needs to be improved, and the rapid stretching Sawarna village tourism, certainly has a good side effect, also the bad side. It is like two sides of a coin. On the bad side, where stalls and huts on the seaside slum of course will create an impression in the eyes of the tourists. But on the other hand, local economies automatically lifted by the type of the micro enterprises.

The political will of the local government indicates still need to be improved. This is where the role of government as policy makers needed to bridge two opposing interests. It is not easy, but it is important that efforts are mutually beneficial synergy realized between the local people with the visitors who come.

Referred to Understanding and cross-cultural tolerance are good as it's reflected in the color of the background of the district as a white color of a Mosque dome, symbol of Islamic Life in the inner population. Pure white mark in the hearts and deeds, like peace and tolerance (Lindawati, 2014).

The presence of clean beaches, challenging waves, and lush tourist village, certainly reinforced the attractiveness Sawarna to visit. If it were so, the rugged terrain and difficult access to reach the village of Sawarna should no longer have an excuse not to visit the hidden paradise (BEM, 2013).

\subsection{Badegur's Coast}

Based on sustainable peace education (Marvis, 2014; Hengky, 2014; Senlier \& Ozturk, 2011; UNWTO, 2014; and Bajaj \& Chiu, 2009), Badegur's coast could address the conflict of space by developing the coast as the basis of peace education $(\mathrm{K}=0.655)$ as it's presented in Table 2. The expression of one parameter of sustainable peace education, which indicated by the performance of sustainable coastal tourism $(\%$ Freq $=26.72)$ and reflecting to an excellence Begedur's Coast. The coast is still quiet and it's located in Lebak Regency. This nature coast tourism is located in the village Sukamanah, Malingping Subdistrict, Lebak District, Banten. Badegur's Coast is about 115 km from the city Rangkasbitung or $83 \mathrm{Km}$ from the district park. After that the tourists can simply enjoy the breeze while walking down the beach. Accompanied by waves romp, a broad expanse of white sand. Decorated with laughter relatives certainly add to the excitement of tourists' vacation at the beach of Badegur (Billy, 2013; Dulang, 2013; and Studio, 2013). 
Moreover, The sand of the Badegur's Coast has the appeal of a soft, clean, spacious without coral, reaching $15 \mathrm{Km}$ in length with a fairly gentle contour of the coast. Extensively the coastal engrossed used to play football, volleyball, cycling, running around, and others. Swimming at the beach is also exciting, but the tourists should be careful because the waves which fairly large it can compromise the safety if they are not careful. Although fairly quiet, but many lined stalls selling food and soft drinks in the coastal region, if the tourists want to bring lunch also allowed, as long as it do not forget to keep back his trash and not pollute the coastal environment. Do not miss a moment of sunset on this beach, for tourists and lovers of marine tourism photography make this one as the object of their photos and a challenge and its own experience (Meir, 2013).

Table 2. Results Tabulation of Badegur's Coast

\begin{tabular}{llc}
\hline Badegur's Coast - Sustainable Peace Education & Value & \% Freq \\
\hline The performance of sustainable coastal tourism & 35 & 26.72 \\
Political will of the local government & 27 & 20.61 \\
Cross-cultural interaction and form interaction & 31 & 23.66 \\
Understanding and cross-cultural tolerance & 38 & 29.01 \\
\hline
\end{tabular}

Kappa Coefficient $=\mathrm{K}=0.655$

The advantages of this beach which attracted many tourists is the condition of the coast up to $10 \mathrm{~km}$ in length and up to 50 meters wide the coast. Coupled with the flatness of these the coasts and dense sand beaches, this beach allows laced by a motor vehicle. Even sometimes the beach is also often used as a rally motor.

When the tourists come to this place, they can instantly bring their vehicles to the edge of the beach while enjoying the rolling surf south coast. Tourists also can freely play with their family on this beach. Conditions rocky beaches aren't making the parents calm their children release at this beach. In addition, on the seaside also being peddled that provides a place to eat seafood with a variety of preparations, of course it can be enjoyed by the tourists at affordable prices. In 2013, through the travel and tourism industry, Indonesia was able to print the 3.04 million jobs, or about 2.7\% of national employment (Wahyuni, 2014; and Wisata, 2013).

Referred to Political will of the local government, and it's indicated that the local government still has not strong effort in developing the infrastructure, which can enhance the performance of the Badegur's coast. It's reflected that this Province is still underdeveloped areas, although geographically, it's located not far from the nation's capital, Jakarta. 
In terms in strengthening cross-cultural interaction and form interaction, surrounding Badegur's coast, there is still have the potential in plantation and agriculture. The plantations expanse of farmland and vast and fertile. Both of these areas can be a center of agribusiness with its superior products. Indeed, many factors that lead to an area be left behind. It could be due to structural factors and cultural factors. In addition, geographical factors and local conditions also contribute to an underdeveloped areas (Zaini, 2010).

Referred to understanding and cross-cultural tolerance, would be developed from the interaction from the tourists and local people. It's not only contribute to an increase in state revenues, the tourism sector also managed to reduce the number of unemployed in the country (Wahyuni, 2014).

\section{Conclusions}

This study is so essential in addressing the conflict over space: social, environmental, and territorial. At the same time it was so important for realizing the development of sustainable peace based on sustainable development (Villiers, 2014; and UNWTO, 2014).

Based on the discussion, this study shows that until now the development of the coastal of Ciantir and Badegur would: Firstly, addressing the space conflict; Increasing income per capita; Secondly, decreasing unemployment and poverty due to the low quality of human resources; and Finally, decreasing degradation of the natural environment (Mangunjaya, 2014; Admin, 2014; Rakhman, 2014; Tarigan, 2014; and World Bank, 2014).

An important step towards Ciantir's Geopark is needed to do the arrangement of the area and community empowerment, but not change what is already there. Instead of the existing state of the capital region is one of the basis for the development of a tourism industry (Oktariadi, 2012).

However, because of the limitation of funding and time, future research could be conducted in more specific by exploring the each part of the parameter of sustainable peace. Hopefully the author could get the chance to conduct the research in each part of them in the very near future. This study analyzes the implementing of the sustainable peace education in the coastal of Ciantir and Badegur.

\section{Implications}

The main point of sustainable peace education, is by promoting and empowering each individual of each tourists and local people in participating in advancing the objectives of peace and ecological sustainability. As a result, it's essential in the reinforcement of peace education and environmental education in the promotion of Sustainable Development, particularly in formal education, non-formal learning channels, and popular culture in building a holistic idea of the ecological responsibility, peace, and social justice. These interactions stimulate dialogue and exchange, break down cultural barriers and promote the values of tolerance, and mutual understanding and respect. However, the values espoused by the tourists is integral to building a future more peaceful and tolerant (Kelman, 1998). 


\section{References}

Admin (2014). Management areas where people want: The latest of natural resources in Indonesia, Sawit Watch. Retrieved from http://sawitwatch.or.id/2014/07/kawasan-kelola-rakyat-mau-kemana-sumberdaya-alam-di-ind onesia-terkini/

Antara (2012). Minister of Tourism and Creative Economy promotes sustainable tourism at the World Economic Forum, Antaranews.com. Retrieved from http://www.antaranews.com/berita/313584/menparekraf

Bajaj, M., \& Chiu, B. (2009). Education for Sustainable Development as Peace Education, Peace \& Change, 34(4), 441-445. Wiley. http://dx.doi.org/10.1111/j.1468-0130.2009.00593.x

Berlin (2014). Indonesian Tourism Growth Exceeds, Tempo.com. Retrieved from http://www.tempo.co/read/news/2014/03/06/202559869/Pariwisata-Indonesia-Lampaui-Pertu mbuhan-Ekonomi

BEM (2013). Cruising By Beach Village Sawarna Ciantir, Simplyindonesia. Retrieved from http://simplyindonesia.wordpress.com/2013/10/10/terios-7-wonders-jelajah-desa-sawarna-hin gga-pantai-ciantir/

Billy, S. (2013). Bagedur Coast Attractions, Banten, balibackpacker.blogspot.com. Retrieved from http://balibackpacker.blogspot.com/2012/12/objek-wisata-pantai-bagedur-banten.html

BPS (2012). The number of poor by province, Central Bureau of Statistics. Retrieved from http://www.bps.go.id/tab_sub/view.php?tabel=1\&id_subyek=23\&notab=1

Brake, W., \& Addo, E. (2014). Tourism and Fracking in Western Newfoundland: Interests and Anxieties of Coastal Communities and Companies in the Context of Sustainable Tourism. International Journal of Marine Science, 4(2), 16-41. Retrieved from http://bio.sophiapublisher.com/index.php/ijms/article/view/1087

Cohen, J. (1960). A Coefficient of Agreement for Nominal Scales. Educational and Psychological Measurement, 20, 37-46. http://dx.doi.org/10.1177/001316446002000104

Dulang (2013). Bagedur, Lonely Beach Beautiful in Banten, Detiktravel.com. Retrieved from http://travel.detik.com/read/2013/02/12/112000/2167336/1025/bagedur-pantai-sepi-nan-canti k-di-banten

Ello, S., \& Kyngas, H. (2008). The qualitative content analysis process. Journal of Advanced Nursing, 62(1), 107-115. http://dx.doi.org/10.1111/j.1365-2648.2007.04569.x

Hengky, S. H. (2014). Excogitated Coastal Tourism Competitiveness by Implementing Eco-tourism in Anyer, Banten, Indonesia. International Journal of Marine Science, 4(7), 74-81. http://dx.doi.org/10.5296/emsd.v3i1.5508

Henderson, K. (1991). Dimensions of Choice: A Qualitative Approach to Recreation, Parks, and Leisure Research, Venture, State College, Australia 
Jenning, G. (2001). Tourism Research, John Willey \& Sons Australia, Ltd, 136-152.

Kelman, H. C. (1998). Building a sustainable peace: The limits of pragmatism in the Israeli-Palestinian negotiations. Journal of Palestine Studies, 28(1), 36-50. http://dx.doi.org/10.2307/2538054

Liliyah, A. (2014). Indonesia Tourism Investment First Quarter 2014 Achieving US \$ 130.13 Million, Swa.co.id. $\quad$ Retrieved from http://swa.co.id/business-research/investasi-pariwisata-indonesia-kuartal-i-tahun-2014-menca pai-us13013-juta-us

Lindawati (2014). Symbolic Meaning of Regency Lebak, Lindawatiblog. Retrieved from http://lindawatisay.wordpress.com/2010/01/05/arti-dan-lambang-kabupaten-lebak/

Mangunjaya, F. M. (2014). Challenges of Managing Natural Resources Jokowi. Koran.tempo.co. Retrieved from http://koran.tempo.co/konten/2014/09/15/351850/Tantangan-Jokowi-Mengelola-Sumber-Day a-Alam

Masun, A. (2014). Ciantir Coast, Kapanlagi.com. Retrieved from http://travel.kapanlagi.com/jakarta/wisata/29702-pantai-ciantir.html

Mavris, C. ( 2011). Sustainable Environmental Tourism and Insular Coastal Area Risk Management in Cyprus and the Mediterranean. In: A, Micallef. (Eds.), MCRR3-2010 Conference Proceedings. Journal of Coastal Research, Special Issue, 61, 317-327. http://dx.doi.org/10.2112/SI61-001.1

Meir, A. (2013). Seeing Eye covering Coastal Beauty Badegur, Banten, Ensiklopedia Indonesia. Retrieved from http://ensiklopediaindonesia.com/wisata-indonesia/wisata-pantai/seluas-mata-memandang-ke indahan-pantai-bagedur-banten/

Milah, S. (2013). Desa Sawarna `Hidden Paradise In Banten', Liputan6.com. Retrieved from http://news.liputan6.com/read/767542/desa-sawarna-hidden-paradise-in-banten

Nara, P., Mao, G., \& Yen, T. (2014). Applying Environmental Management Policy for Sustainable Development of Coastal Tourism in Thailand. International Journal of Environmental Protection and Policy, 1, 19-23. Retrieved from http://article.sciencepublishinggroup.com/pdf/10.11648.j.ijepp.20140201.13.pdf

Oktariadi, O. (2012). Gulf Ciantir, Biological Diversity in the Bayah dome. GEOMAGZ, 2(1), 26-38.

Partodirejo, N. (2012). In Picture: Exploring AdventurePicnicHolic Sawarna, Republika Online. Retrieved from http://www.republika.co.id/berita/komunitas/picnicholic/12/05/15/m41s3p-petualangan-picni cholic-menjelajahi-sawarna 
Rakhman, E. (2014). Coordinating Minister for the Environment \& Natural Resources Cabinet Jokowi - JK Must Right, Effective, Obey the Law and Freedom, Regional Kompasiana. Retrieved from http://m.kompasiana.com/post/read/684058/1/walhi-menko-lh-sda-untuk-kabinet-jokowi-jk-h arus-tepat-efektif-taat-hukum-dan-merdeka.html

Riffe, D., Lacy, S., \& Fico, F. (1998). Analyzing Media Massage: Using quantitative content analysis research (3rd Edition), Routledge, 18-71

Senlier, N., \& Ozturk, G. (2011). Investigation of Fragility to Estimate Tourism Pressure. Journal of Coastal Research, pp. 217-220. http://dx.doi.org/10.2112/SI61-001.17

Studio, O. (2013). Beautiful Beach Badegur which unspoiled, Yukpergi.com. Retrieved from http://www.yukpegi.com/wisata/wisata-alam/pantai-bagedur-nan-cantik-yang-belum-terjama $\mathrm{h} /$

Tarigan, A. (2014). Deprivation of Natural Resources and Democratization in Natural Resource Governance: Opportunities for New Indonesian Government, Wahli. Retrieved from

https://translate.google.com/\#id/en/Perampasan\%20Sumber\%20Daya\%20Alam\%20dan\%20

Demokratisasi\%20dalam\%20Tata\%20Kelola\%20Sumber\%20daya\%20Alam\%3A\%20Peluan g\%20bagi\%20Pemerintahan\%20Baru\%20Indonesia

Villiers, D. D. (2014). Cornerstones for better world: Peace, tourism \& sustainable development In Wohlmuther, C., \& Wintersteiner (Eds.) International Handbook on Tourism and Peace, Centre for Peace Research Education of the Klagenfurt University, Austria in cooperation with World Tourism Organization (UNWTO). Retrieved from http://www.uni-klu.ac.at/frieden/downloads/International_Handbook_on_Tourism_and_Peac e(2).pdf\#page $=17$

Wahyuni, N. D. (2014). Indonesian Tourism Sector 3 Million Results Job Vacancy, Liputan 6. Retrieved from http://bisnis.liputan6.com/read/2025616/sektor-pariwisata-indonesia-cetak-3-juta-lowongan-k erja

Wisata, G. (2013). Privileges and Beauty, Coastal Bagedur, Gudang Wisata. Retrieved from http://www.gudangwisata.com/keistimewaan-dan-keindahan-pantai-bagedur.html

Wisata, T. (2011). The Treasure Coast Sawarna Banten, 12, 64-65. Trans Media.

UNWTO (2014). International Handbook on Tourism and Peace, the World Tourism Organization and the Government of Austria, Vienna, Madrid. Retrieved from http://media.unwto.org/press-release/2014-01-31/international-handbook-tourism-and-peace-l aunched-unwto-and-government-aust

World Bank (2014). Poverty Decline in Indonesia Slow, Inequality Rises, The World Bank Group.

from 


\section{Macrothink}

Journal of Management Research ISSN 1941-899X 2014, Vol. 6, No. 4

http://www.worldbank.org/in/news/press-release/2014/09/23/poverty-reduction-slows-inequa lity-increases-world-bank-reports

Zaini, H. F. (2010). Saijah country and Adinda, Opini Republika, 5. Retrieved from http://ftp.unpad.ac.id/koran/republika/republika_2010-09-29.pdf 